${ }^{3}$ Cohn PF, Gorlin R, Cohn LH, Collins JJ. Left ventricular ejection fraction as a prognostic guide in surgical treatment of coronary and valvular heart disease. Am $\mathcal{F}$ Cardiol 1974 ;34:136-41.

4 Borow KM, Green LH, Mann T, et al. End-systolic volume as a predictor of postoperative left ventricular performance in volume overload from valvular regurgitation. $A m \mathcal{F}$ Med 1980;68:655-63.

5 Saltissi S, Crowther A, Byrne C, Coltart DJ, Jenkins BS, Webb-Peploe MM. Assessment of prognostic factors in patients undergoing surgery for non-rheumatic mitral regurgitation. Br Heart $\mathcal{F}$ 1980;44:369-80.

- Rosenblatt A, Clark R, Burgess J, Cohn K. Echocardiographic assessment of the level of cardiac compensation in valvular heart disease. Circulation $1976 ; 54: 509-18$

${ }^{7}$ McDonald IG. Echocardiographic assessment of left ventricular function in mitral valve disease. Circulation 1976;53:865-71.

${ }^{8}$ Schuler G, Peterson KL, Johnson A, et al. Temporal response of left ventricular performance to mitral valve surgery. Circulation 1979;59: 1218-31.

9 Carpentier A, Chauvaud S, Fabiani JN, et al. Reconstructive surgery of mitral valve incompetence. Ten-year appraisal. $\mathcal{f}$ Thorac Cardiovasc Surg 1980;79:338-48.

10 Cohn LH, Mudge GH, Pratter F, Collins JJ. Five to eight-year follow-up of patients undergoing porcine heart-valve replacement. $N \mathrm{Engl} \mathrm{F} \mathrm{Med}$ $1981 ; 304: 258-62$.

\section{Pulmonary problems of the immunocompromised patient}

The protective cuticle surrounding the body is deficient from mouth to anus. The lungs present an area of naked mucous membrane almost the size of a football pitch, making it scarcely surprising that they are the most common site of entry for pathogens. The chances of infection are narrowed by a field of defences set in readiness. IgA-laden mucus at the bronchi and IgG in the alveoli are both dependent on normal function of the thymic-independent, B-cell lymphocytes. Alveolar macrophages, regarded by some as the linchpin of pulmonary defence, depend on normal function of the thymicdependent, $\mathrm{T}$-cell lymphocytes and their free-ranging lymphokines. ${ }^{1}$

Understanding of these mechanisms has become more important in recent years as patients have their defences suppressed, either as an unwanted side effect of cancer chemotherapy or deliberately in an effort to induce the host to accept transplanted foreign tissue. In such patients the physician should expect an increased chance of infection with common bacterial pathogens, but these can usually be identified either in sputum or in blood and controlled with broad-spectrum antibiotics. The more difficult problems are caused by the truly "opportunistic" agents-those organisms which infect only immunosuppressed patients, which are often difficult or impossible to isolate and which may fail to respond to conventional treatment. In practical terms the worried physician needs to know when to suspect opportunistic lung infection, how to isolate the organism responsible, and how to treat the patient.

The clinical setting is one of fever, shortness of breath, and unproductive cough in a patient with a pulmonary infiltrate in the chest radiograph. The shadowing produced is in no way characteristic but may provide a clue to the causative agent in a few instances. ${ }^{2}$ In immunosuppressed patients with tissue transplants the diagnosis may be clear cut, but the picture is more complicated in patients receiving treatment for tumours, especially leukaemia, because the primary disease itself may be responsible for lung changes. Tenholder and Hooper ${ }^{3}$ suggest that an opportunistic infection is more likely if the pulmonary infiltrate is diffuse and does not occur within three days of a pulse of cytotoxic treatment.

Opportunistic organisms cause great difficulties for microbiologists. They often demand the most bizarre nutritional requirements, and on many occasions more than one pathogen may be present. In a prospective study by Singer et al ${ }^{4}$ of 80 patients with lung infiltrates, many of whom had leukaemia, the most extensive laboratory investigations identified a cause in only a third. When open-lung biopsy was added to the investigations the success rate was improved to two-fifths. Nevertheless, in a little over a fifth of the cases no infecting agent was found either on open-lung biopsy or at necropsy.

Heading the list of opportunists is Pneumocystis carinii, accounting for $38 \%$ of lung infiltrates in the series reported by Singer et $a l^{4}$ and 33\% in Tenholder and Hooper's study. ${ }^{3}$ The incidence among patients with transplants is lower, reported at $12 \%$ in one series of renal transplant recipients, probably because of their lower degree of immunosuppression. ${ }^{5}$ Running Pneumocystis a close second are fungal infections, especially with Candida spp and Aspergillus fumigatus, and viruses such as cytomegalovirus and herpes simplex. With improved diagnostic techniques an increasing number of exotic and unusual diseases are being unearthed. Recently a hitherto unknown organism, similar in staining properties to the tubercle bacillus, has been identified by open-lung biopsy and subsequently dubbed the "Pittsburgh pneumonia agent," after the city in which it was first isolated. ${ }^{6}$ ?

Open-lung biopsy is a major procedure for any seriously ill patient who already has diseased lungs, and many British physicians are reluctant to pursue investigations to that extent. Having excluded infection with common bacterial pathogens these pragmatists will give high doses of co-trimoxazole on the assumption that the infection is due to Pneumocystis. Scientific purists may object to this "cook-book" approach, but such pragmatism often pays off.

1 Green GM, Jakab GJ, Low RB, Davis GS. Defense mechanisms of the respiratory membrane. Am Rev Respir Dis 1977;115:479-514.

2 Greene R. Opportunistic pneumonias. Semin Roentgenol 1980;15:50-72.

3 Tenholder MF, Hooper RG. Pulmonary infiltrates in leukemia. Chest $1980 ; 78,3: 468-73$.

${ }^{4}$ Singer C, Armstrong D, Rosen PP, Walzer P, Yu B. Diffuse pulmonary infiltrates in immunosuppressed patients. Am 7 Med 1979;66:110-20.

5 Munda R, Alexander JW, First MR, Gartside PS, Fidler JP. Pulmonary infections in renal transplant recipients. Ann Surg 1978;187:126-33.

${ }^{6}$ Rogers BH, Donowitz GR, Walker GK, Harding SA, Sande MA. Opportunistic pneumonia. A clinicopathological study of five cases caused by an unidentified acid-fast bacterium. N Engl f Med 1979;301 : 959-61.

${ }^{7}$ Myerowitz RL, Pasculle AW, Dowling JN, et al. Opportunistic lung infection due to "Pittsburgh pneumonia agent." $N$ Engl f Med 1979; 301 : $953-8$.

\section{Hazards of biliary tract surgery}

Operating on the biliary tract of patients with obstructive jaundice is hazardous; the immediate mortality is broadly correlated with the depth of jaundice. Factors which may increase the risks of operation include cholangitis and predisposition to septicaemia, ${ }^{1}$ impaired renal function with a low glomerular filtration rate, ${ }^{2}$ malnutrition with hypoalbuminaemia, failure of hepatic reticuloendothelial cells to remove endotoxin from the portal venous blood, ${ }^{3}$ and depres- 